\title{
Evaluation of in-vitro Immunomodulatory Activity and Thrombolytic Potential of Kabasura Kudineer (KSK): An Official Siddha Polyherbal Formulation
}

\author{
Sathiyarajeswaran Parameswaran ${ }^{11}$, Shree Devi Munusamy Sampangi Ramulu1",*, \\ Vishnu Kirthi Arivarasan ${ }^{2 \#, ~ K a n a k a v a l l i ~ K a d a r k a r a i ~}{ }^{3}$, Ramesh Kumar Dhanakoti ${ }^{4}$, Karthik Loganathan $^{4}$ \\ ${ }^{1}$ Siddha Central Research Institute, Chennai, Tamil Nadu, INDIA \\ ${ }^{2}$ National Centre for Nanoscience's and Nanotechnology, University of Mumbai, Vidyanagari, Santa Cruz (E), Kalina Campus, \\ Mumbai, Maharashtra, INDIA. \\ ${ }^{3}$ Central Council for Research in Siddha, Ministry of AYUSH, Chennai, Tamil Nadu, INDIA. \\ ${ }^{4}$ Research and Development Centre, Salem Microbes Private Ltd., Salem, Tamil Nadu, INDIA. \\ "Equal First Authorships
}

\begin{abstract}
Aim: Coronavirus disease 2019 (COVID-19) caused by the Severe Acute Respiratory Syndrome Coronavirus 2 (SARS-CoV-2), attacking mainly on the immune system of a body. This has spread mortality and morbidity all over the world. During this dreadful situation there is an urgent need for the development and rapid dissemination of COVID-19 treatment. Siddha's traditional medicine system can be used as preventive care to boost the immune system. Materials and Methods: The immense treasure of knowledge found in Siddha medicine can help mortality. Kabasura Kudineer (KSK) is one of the Siddha poly herbal formulation used as an immune-boosting agent against several diseases. Results: In the present study the KSK has been investigated for its effects of immunomodulatory and thrombolytic potential. The KSK at the concentrations of $12.5,25,50$, and 100 $\mu \mathrm{g} / \mathrm{ml}$ showed \% immune-stimulations of $12.40 \%, 20.81,33.53$, and 43.20 and for NBT showed $19.00,25.50,64.00,71.00 \%$ respectively. Moreover, similarly, the thrombolytic activity showed 50 , and $100 \mu \mathrm{g} / \mathrm{ml}$ concentration showed $43.83 \%$, $71.83 \%$ clot lysis, respectively, and the control value for the Streptokinase showed $83.78 \%$. Conclusion: Hence, it can be confirmed that KSK has immunomodulatory and thrombolytic properties in vitro models. Immunomodulatory and anti-thrombolytic are the steps to create a stable, safe, and efficient COVID-19 cure.
\end{abstract}

Key words: Kabasura Kudineer (KSK), Immunomodulatory, Thrombolytic, COVID-19, Siddha formulation.

\section{INTRODUCTION}

As a rule, current human healthcare services are significantly tested and challenged by the SARS-CoV-2 with its indisputable complex biochemical architecture. Its present momentum is very much persistent, making a predictable second wave. ${ }^{1}$ The human respiratory system is very much vulnerable to different viral infections starting from coronavirus, rhinovirus, human metapneumovirus, and the human immune system is significantly affected during COVID-19 progression in the infected host. ${ }^{2}$ Skowronski,
Astell $^{3}$ had reported respiratory disease result in a cytokine-chemokine reaction resulting in severe damage to the host.

The role of immunology was the most rapidly developing scientific area and showed an evolving opportunity in the treatment and prevention of disorders, inflammatory reactions of different parts of the human body. Similarly, the infections are considered immunological diseases, whereas the neoplastic and autoimmune diseases occur in immunosuppressed state. ${ }^{4}$ It is reported
Submission Date: 02-01-2021; Revision Date: 03-03-2021; Accepted Date: 02-06-2021

DOI: 10.5530/ijper.55.3.150 Correspondence: Dr. M. S. Shree Devi Research Officer, Department of Pharmacy, Siddha Central Research Institute, Ministry of AYUSH, Arumbakkam,

Chennai-600106, Tamil Nadu, INDIA Phone no: +919443056180 Email id: shreemd@gmail. com

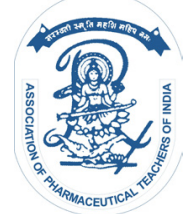

www.ijper.org 
that many of the synthetic, semi-synthetic and natural therapeutic agents have a suppressive and cytotoxic nature which support the immune system. ${ }^{1,5-7}$

In today's health wellness commerce, the role of immunomodulators is well-established as a critical component. These immunomodulators are grouped into three main classes: immunosuppressants, immunostimulants, and immunoadjuvants, and their applications in medicine and pharma industries for stimulation and suppression of the immune system. Also, these are used as both prodrugs and prophylactic drugs for the healthy populace. ${ }^{8,9}$ Also, the plant kingdom's immunomodulators seem to be a good substitute for the synthetic chemical compounds. ${ }^{10}$

The World Health Organization has put a public health emergency by putting COVID-19 as a transnational threat. ${ }^{11,12}$ There is no medicine or prophylactic treatment for this disease and has been constrained towards palliative help to the affected people. Hence, there is a dire need to produce a safe and stable COVID-19 immunisation.

The current trending strategies for the COVID-19 treatment plan have been focused on immunisation against the virus and head-on attack on the virus particle. This makes the host a vital factor in ailment's subtleties. Siddha medicine is always aimed towards a healthy routine rather than just an issue of medicine.

Immunity is termed Vanmai in Siddha, and it has a direct association with Uyir thathukeal (Vali, Azhal and Aiyam) and Seven Udal thathukekal (Body tissues). Natural immunity of the human body by birth is called Iyarkai Vanmai, its improvement with the help of intake of balanced food and medicines is called Seyarkai Vanmai and Kala vanmai, which is further defined as the change of physical state under the effects of seasons and in their affected state there might be possibilities of disease. ${ }^{13-15}$ Human beings are the subtotal of Uyir thathukeal and Udalthathukeal forming his/her physical solid and mind results in a robust immune system. Individuals with the Vali trait have lesser immunity, while persons of Aiyam have moderate immunity, and persons are having Aiyam have stronger immunity compared to each other. The Siddha medicinal system has thoroughly tested the herbs and the polyherbal formulations via in vitro and in vivo, including the Urai mathirai, Saya chooranam, Nilavembu kudineer, which are very much beneficial. ${ }^{16-18}$ The botanicals used in Kayakalpa are effective in immunomodulation and restoration of immune homeostasis. ${ }^{19}$ Most of the Siddha medicines are found to be present in the mixture or consists of more than plant or their extracts. Some of the recent literatures have stated the importance of synergistic effects of the traditional medicines and plant extracts. Yang, Zhang ${ }^{20}$ and his co-workers have detailed about the Chinese herbs and their synergistic effects on different biological pathways. Similarly, the potential synergistic effects of plant based biomolecules have been well studied on SARS-CoV-2 by Prasad, Muthamilarasan. ${ }^{21}$ The synergistic combination of molecules interacts with target-disease networks which provide novel, mechanistic insights towards understanding their therapeutic potentials. ${ }^{22}$ The docking studies carried out by us for better understanding KSK extract revealed a pathway to understanding the Siddha in a scientific manner. ${ }^{23}$

The COVID-19 infection cycle has two distinct phases in which the first protective phase of the adaptive immune response in a host might eliminate the virus. ${ }^{24}$ In the current situation, hydroxychloroquine is considered a candidate for COVID-19 treatment due to its Immunomodulatory and antiviral effects. ${ }^{25,26}$ The COVID-19 leads to blood clots in people with a severe form of the COVID-19 disease. Blood clots cause a severe problem in the blood circulatory system. Blood clots in the form of thrombus hamper blood flow in blood vessels, reducing the oxygen intake to the tissues. The fibrinolytic drug dissolves the clot trapped in coronary vessels, restoring the heart's blood, limiting the necrosis. ${ }^{27}$ The tissue plasminogen activator, urokinase and Streptokinase are drugs prescribed as thrombolytic agent nowadays by physicians. The Indian population has been prescribed Streptokinase and urokinase due to their low cost, ${ }^{25,26 \text {, }}$ and other drugs with the hyper risk of haemorrhage..$^{28,29}$ The COVID-19 is a trending research topic that is being researched again in every developed country. The research papers are being published in almost every branching scientific field from biotechnology, bioinformatics, physics, chemistry and many others. The traditional medicines are also involved in this research racetrack to curb the pandemic COVID-19. Siddha Medicine is a treasured healing desire that is classically used for treating viral pulmonary infections; this precept of drugs is confirmed to incorporate antiviral compounds. The Siddha medicine is prescribing KSK for the treatment of fever and as prophylactic antiviral agents. ${ }^{30}$ At present, the Ministry of AYUSH's guidelines, Government of India, KSK, is given for boosting immunity among the ordinary people $e^{30}$ but not limited to prophylaxis and so that we can take to the integrative model of therapeutics. For selecting Siddha Medicine's safety, Efficacy and availability have to be addressed. However, the immunomodulatory activity and thrombolytic activity of Kabasura Kudineer has not been reported or scientifically investigated. Therefore, 
the present study focused on investigate the immunomodulatory and thrombolytic potential of KSK.

\section{MATERIALS AND METHODS}

Kabasura Kudineer Chooranam is a compound formulation consisting of fifteen ingredients which are given in Table 1. Kabasura Kudineer Chooranam was purchased from Tamil Nadu Medicinal Plant Farms and Herbal Medicine Corporation Limited (TAMPCOL). All the chemicals and solvents are of analytical grade, obtained and used in the same condition. The Candida albicans suspension (MTCC-183) was purchased from Microbial Type Culture Collection and Gene Bank (MTCC), Chandigarh, India.

\section{Extraction of the KSK and sample preparation}

The dried KSK powder was weighted and was packed in Soxhlet apparatus and refluxed with distilled water. The extracts were pooled, filtered, dried, and stored below $5^{\circ} \mathrm{C}$ till further use. Doses such as $12.5,25,50$, and $100 \mu \mathrm{g} / \mathrm{ml}$ were prepared in the isotonic solution for in vitro immunomodulatory activity.

\section{In vitro immunomodulatory activity by Phagocytosis of Candida albicans assay}

Phagocytosis of Candida albicans test was carried out according to method. ${ }^{31-33}$ The Sabouraud's dextrose broth was inoculated with C. albicans (MTCC-183) and was incubated overnight. The C. albicans was then washed with Hank's balanced salt solution and was subjected to centrifugation four times, and the final cell pellet was again mixed sterile Hank's balanced salt solution and

\begin{tabular}{|c|c|}
\hline \multicolumn{2}{|c|}{ Table 1: Kabasura Kudineer ingredients. } \\
\hline S.No. & Ingredients \\
\hline 1 & Zingiber officinale Rosc \\
\hline 2 & Piper longum L \\
\hline 3 & Syzygium aromaticum \\
\hline 4 & Tragia involucrata $L$ \\
\hline 5 & Anacyclus pyrethrum \\
\hline 6 & Andrographis paniculata \\
\hline 7 & Terminalia chebula Retz. \\
\hline 8 & Justicia adhatoda L. \\
\hline 9 & Costus speciosus \\
\hline 10 & Plectranthus amboinicus (Lour) Spreng \\
\hline 11 & Clerodendrum serratum L. \\
\hline 12 & Sida acuta Burm. f. \\
\hline 13 & Cypreus rotundus L. \\
\hline 14 & \\
\hline 15 & \\
\hline
\end{tabular}

human serum ratio of $4: 1$. In the present experimentation, the concentration of cells used was $1 \times 10^{8}$.

\section{Evaluation of Phagocytosis}

As per Ponkshe and Indap, ${ }^{31}$ the estimation of the phagocytosis was performed. The finger prick method was employed to assess the phagocytosis by placing a drop of blood sterile glass slide preincubated at $37^{\circ} \mathrm{C}$ for $25 \mathrm{~min}$. Sterile saline was used to isolate the clot; care was taken not to wash away adhered neutrophils. The KSK extract was tested in $12.5,25,50$, and $100 \mu \mathrm{g} / \mathrm{ml}$ concentrations and pooled serum was used a standard and were incubated at $37^{\circ} \mathrm{C}$ for $15 \mathrm{~min}$. This step was followed by predetermined $C$. albicans suspension concentrations and was further incubated at $37^{\circ} \mathrm{C}$ for $60 \mathrm{~min}$. After this, slides were drained, fixed using methanol and were stained using Giemsa stain. The assessment of the phagocytosed number of $C$. albicans cells by neutrophils was carried out microscopically. The number of Candida cells phagocytosed/engulfed by a neutrophil is Phagocytic index (P.I.), and the study was performed in triplicates. Immunostimulation was calculated in percentage using the following equation.

$$
\% \text { of Simulation }=\frac{\text { PI }(\text { samples })-\text { PI }(\text { control })}{\text { PI }(\text { control })} \times 100
$$

Where, the Immunostimulation \% = PI (samples) - PI (control) / PI (control) $\times 100$. Were, P.I. of samples: Phagocytic index of the test sample, P.I. of control: Phagocytic index without the test sample (i.e., normally by neutrophils).

\section{Nitroblue Tetrazolium Assay}

The test was performed as described as Mali, Hatapakki ${ }^{34}$ described with minor modification. Leucocyte suspension $\left(5 \times 10^{6} / \mathrm{ml}\right)$ in phosphate buffer saline (PBS) was taken in all Eppendorf tubes as per Dagur and McCoy. ${ }^{35} 100 \mu \mathrm{l}$ of PBS was added into first Eppendorf tube and was used as control, second Eppendorf tube was added with $100 \mu \mathrm{l}$ of lipopolysaccharide $(10 \mu \mathrm{g} / \mathrm{ml})$ was used as standard, and the remaining Eppendorf tubes were added with $100 \mu \mathrm{l}$ of different concentration (12.5, 25, 50 , and $100 \mu \mathrm{g} / \mathrm{ml}$ ) of the Kabasura Kudineer extract. All these Eppendorf tubes were further added with $200 \mu \mathrm{l}$ of $0.15 \%$ NBT solution and were incubated for $20 \mathrm{~min}$ at $37^{\circ} \mathrm{C}$. After incubation, the Eppendorf tubes were centrifuged for 3-4 min at $400 \mathrm{~g}$, and the supernatant was discarded. Further, the cells were treated with a small PBS solution, and a thin film was made with the drop on the clean glass slide. The slides were then dried, fixed by heating, and were countered stained with carbol-fuchsin for $15 \mathrm{~s}$. The percentage of NBT 
positive cells with blue lumps or granules was determined by observing the stained slides for blue colour cells/ lumps/granules under $40 \mathrm{X}$ objective for 200 cells. All the experiments were carried out in triplicates, and the results are expressed as mean \pm S.D.

$\%$ of NBT positive cells $=\frac{\text { observing blue color cells }}{200 \text { cells }} \times 100$

\section{In vitro thrombolytic activity of KSK}

\section{Preparation of Streptokinase (S.K.)}

The lyophilised S.K. vial of 15,00,000 I.U was correctly mixed with $5 \mathrm{ml}$ phosphate-buffered saline. This suspension was labelled stock from which dilutions were made to thrombolytic activity as per the in vitro model developed in our lab..$^{36,37}$

\section{Determination of thrombolytic activity}

Three millilitres of venous blood were distributed in four different Eppendorf tube. The thrombolytic activity was performed by preincubating the Eppendorf tubes at $37^{\circ} \mathrm{C}$ for 45 mins. Subsequently, the clot formation was followed with the removal of serum without disturbing the clot. The clot weight was determined using the formula; Clot weight $=$ weight of clot filled tube - Weight of empty tube alone. With pre-weighted clot, $100 \mu \mathrm{l}$ of KSK extract was added to these tubes, and for the standard, $100 \mu \mathrm{l}$ of Streptokinase and negative nonthrombolytic control - $100 \mu$ of distilled water were separately added to the control Eppendorf tubes. Incubation followed for $90 \mathrm{~min}$ at $3^{\circ} \mathrm{C}$ and was observed for clot lysis. After which, the fluid was removed, and the tubes were weighted to observe a weight difference of. ${ }^{37}$ The difference obtained in weight taken before and after clot lysis was expressed as the percentage of clot lysis is shown below:

$\%$ of clot lysis $=\left(\frac{\text { Weight of lysis clot }}{\text { Weight of clot before lysis }}\right) \times 100$

\section{Statistical analysis}

Tests were carried out in triplicate for three separate experiments. Results were expressed as Mean \pm standard deviation. $P<0.05$ was considered significant and was expressed graphically.

\section{RESULTS AND DISCUSSION}

An immunomodulatory agent from the plant or animal kingdom increases the human body's immune system with the activation of non-specific immune responses. Different plants have tested for their immunostimulant and immunosuppressive properties. In support of this statement, many traditional medicine system concepts of preventive health care and the therapeutic potential have been tested and reviewed in detail. ${ }^{32,38}$ The Ministry of AYUSH has issued guidelines for the Siddha practitioners for COVID-19 for different antiviral and immunity booster formulations, including KSK and Nilavembu Kudineer. We have reported docking studies of bioactive compounds from KSK, ${ }^{23}$ which confirmed that this extract has excellent binding efficiency with spike protein of SARS-CoV-2. Further, in this study, we also explored the immunomodulatory and thrombolytic activity of KSK.

The in vitro immunomodulatory activity of the KSK extract have illustrated in Figure 1. The percentage of killed C. albicans have found to be near to the control sample (serum). This graph substantiates the immunomodulatory property of KSK. Similar results have been observed in Rhododendron arboreum leaves, ${ }^{32}$ Euphobia birta, ${ }^{33}$ similarly, many plant isolated compounds have been reported to immunomodulating nature. The vincristine as an immunosuppressant has been employed for treating thrombotic thrombocytopenic purpura or chronic idiopathic thrombocytopenic purpura. ${ }^{39}$ This alkaloid compound has also been utilised to treat many more diseases: idiopathic thrombocytopenia purpura, bladder cancer, cervical cancer, non-small-cell lung cancer, autoimmune haemolytic anaemia, neck cancer, and head cancer. ${ }^{39,40}$

Nitroblue tetrazolium test assesses the test compound's immunomodulatory activity by determining its ability to stimulate the phagocytic activity in leucocytes. Once stimulated, the membrane-permeable, water-soluble, yellow-coloured nitroblue tetrazolium is reduced to blue NBT formazan crystals by the leucocytes. The KSK extract stimulated the leucocytes' phagocytic activity in a concentration-dependent manner, as seen by the

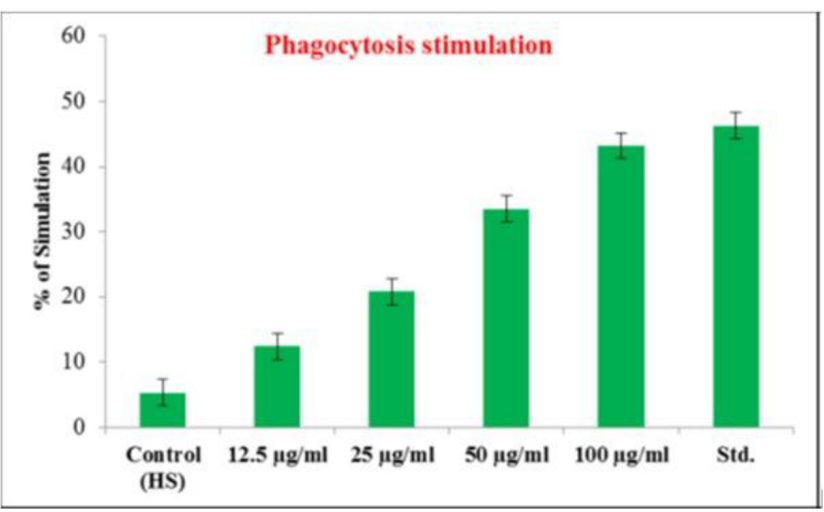

Figure 1: Percentage of killed Candida after treatment with extract by phagocytosis stimulation. 
increased percentage of NBT positive cells, shown in Figure 2. The immunomodulatory effect with the aid of nitro blue assay has been observed in Ficus glomerata Roxb. ${ }^{41}$ Nelumbo nucifera Gaertn. ${ }^{42}$ Pouteria cambodiana. ${ }^{43}$ The study's result indicates the functionality of the neutrophils in the process of phagocytosis is high, creating a proactive environment from the infection.

The COVID-19 patients have shown thrombosis as one of the symptoms. ${ }^{44,45}$ Also, thrombus formation leads to progressive respiratory failure, ${ }^{46}$ myocardial infarction, systemic arterial embolism in COVID-19 patients. ${ }^{47}$ The effective thrombolytic percentages with different concentration of the KSK extract, control, 50 and $100 \mu \mathrm{g} / \mathrm{ml}$ and standard (S.K.) showed 22.36, 43, 71.83 and $83.75 \%$, respectively has been illustrated in Figure 3. From Figure 3, it is evident that the percentage of the thrombolytic activity was $71.83 \%$ at $100 \mu \mathrm{g} / \mathrm{ml}$ compared to the $100 \mu \mathrm{l}$ Streptokinase. From the different samples, the $50 \mu \mathrm{g} / \mathrm{ml}$ showed $43 \%$ thrombolytic activity, which is higher than the distilled water

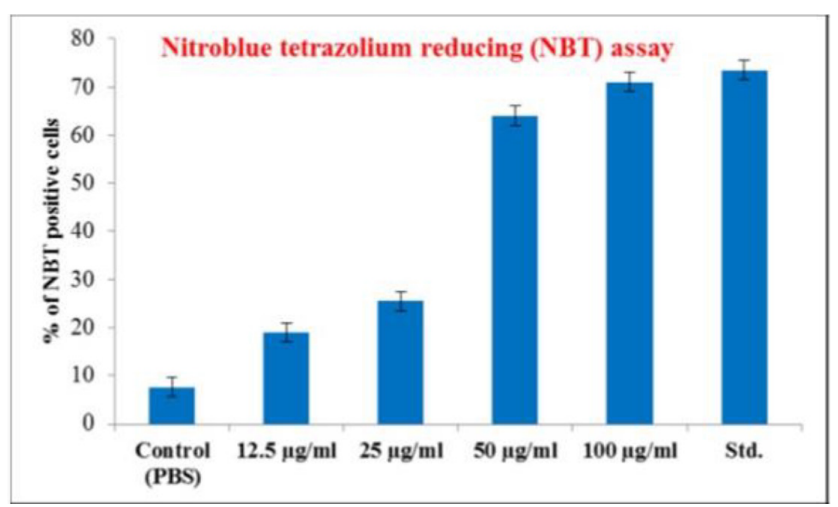

Figure 2: Percentage of NBT positive cells after treatment with extract by Nitro blue Tetrazolium Test (NBT).

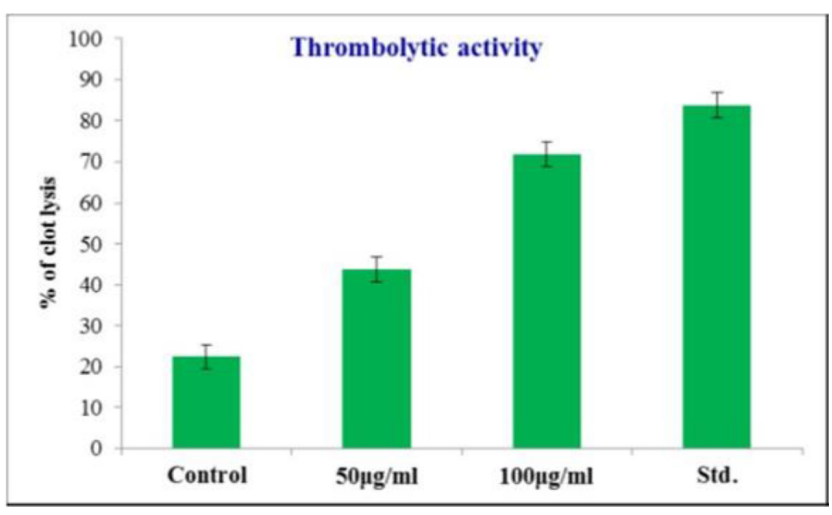

Figure 3: Thrombolytic activity (in terms of \% clot lysis) of sample. (negative control). Kiran ${ }^{23}$ have already reported the phytoconstituents of Siddha formulation KSK. These compounds have been detailed of their biological activities; some of them were found to have thrombolytic, immunomodulatory, anti-inflammatory, and fibrinolytic activity, for example, $\beta$-bisabolene, ${ }^{48-51}$ piperine, ${ }^{52-54}$ Squalene ${ }^{55,56}$ Chebulagic acid, ${ }^{57}$ Carvacrol, ${ }^{58,59}$ Luteolin $^{60,61}$ Magnoflorine. ${ }^{62-64}$

As per Siddha, stickiness, mucilaginous, rounded, little hard are listed as characters of Aiyam. A thrombus has all the qualities of increased Aiyam; most of the thrombolytic drugs are pungent and bitter. Kabasura Kudineer has already been screened for its anti-atherogenic property. The results also suggest the thrombolytic potential of Kabasura Kudineer owing to its fire-based elements in the ingredients. We have reported docking studies of bioactive compounds from Kabasura Kudineer, ${ }^{23}$ which confirmed that this extract has excellent binding efficiency with spike protein of SARS-CoV-2.

\section{CONCLUSION}

Siddha medicine is one of the best ways to control the COVID-19. The immunomodulatory and antithrombolytic are the stepping stones to developing a stable, safe, and working cure for COVID-19. Kabasura kudineer is a polyherbal decoction with fifteen different components, and each of them is in itself a firmly established herbal plant whose synergistic activity might probably improve human immune response and lead the human body to healthiness. The immunomodulatory property and thrombolytic activity of this miracle Siddha medicines have been studied using in vitro experiments but still require in vivo animal model experiments to understand better. This research paper has indicated and supported the notion of using the KSK extract to improve the immune response in this COVID-19 infected time.

\section{ACKNOWLEDGEMENT}

The authors thank all the institutes for their support to carry out this research and thanks to Central Council for Research in Siddha, Ministry of AYUSH, Chennai, Tamilnadu, India and Salem Microbes Private Limited Salem, Tamil Nadu, India.

\section{CONFLICT OF INTEREST}

The authors declare no Conflict of interest. 


\section{ABBREVIATIONS}

KSK: Kabasura Kudineer; MTCC: Microbial Type Culture Collection and Gene Bank; C. albicans: Candida albicans; P.I: Phagocytic index; PBS: Phosphate buffer saline; NBT: Nitroblue Tetrazolium; S.K: Streptokinase; I.U: International unit.

\section{REFERENCES}

1. Cyranoski D. 'We need to be alert': Scientists fear second coronavirus wave as China's lockdowns ease. Nature. 2020.

2. Schmidt ME, Varga SM. The CD8 $T$ cell response to respiratory virus infections. Front Immunol. 2018;9:678. doi: 10.3389/fimmu.2018.00678, PMID 29686673.

3. Skowronski DM, Astell C, Brunham RC, Low DE, Petric M, Roper RL, Talbot PJ, Tam T, Babiuk L. Severe acute respiratory syndrome (SARS): a year in review. Annu. Rev. Med. 2005 Feb 18;56:357-81. doi: 10.1146/annurev. med.56.091103.134135, PMID 15660517.

4. Ziauddin $M$, phansalkar $N$, patki $P$, diwanay $S$, patwardhan $B$. Studies on the immunomodulatory effects OF ASHWAGANDHA. J Ethnopharmacol. 1996;50(2):69-76. doi: 10.1016/0378-8741(95)01318-0, PMID 8866726.

5. Shavit Y, lewis JW, Terman GW, Gale RP, Liebeskind JC. Opioid peptides mediate the suppressive effect OF stress on natural killer cell cytotoxicity. Science. 1984;223(4632):188-90. doi: 10.1126/science.6691146, PMID 6691146.

6. Manderville RA. Synthesis, proton-affinity, and anti-cancer properties of the prodigiosin-group natural products. Curr Med Chem Anticancer Agents. 2001;1(2):195-218. doi: 10.2174/1568011013354688, PMID 12678767.

7. Ren $Y$, Kinghorn $A D$. Natural product triterpenoids and their semi-synthetic derivatives with potential anticancer activity. Planta Med. 2019;85(11-12):802-14. doi: 10.1055/a-0832-2383, PMID 30658371.

8. Shukla S, Bajpai VK, Kim M. Plants as potential sources of natural immunomodulators. Rev Environ Sci Biotechnol. 2014;13(1):17-33. doi: 10.1007/s11157-012-9303-x.

9. El Enshasy HA, Hatti-Kaul R. Mushroom immunomodulators: unique molecules with unlimited applications. Trends Biotechnol. 2013;31(12):668-77. doi: 10.1016/j.tibtech.2013.09.003, PMID 24125745.

10. Patwardhan B, Kalbag D, Patki P, Search NBJID. of immunomodulatory agents: a review. 1990;28(2):56-63

11. World Health Organization. Laboratory testing of 2019 novel coronavirus (" 2019-nCoV)' in suspected human cases: interim guidance, 17 January 2020.

12. Wu JT, Leung K, Leung GM. Nowcasting and forecasting the potential domestic and international spread of the 2019-NCOV outbreak originating in Wuhan, China: a modelling study. Lancet. 2020;395(10225):689-97. doi: 10.1016/S0140-6736(20)30260-9, PMID 32014114.

13. Govindammal P. An open clinical study on Kalladaippu (urolithiasis) with the evaluation of Siddha drug Vediyuppu Chendooram. Government Siddha Medical College. Chennai; 2016.

14. Rajeshwari M. A study on the symptomatology and diagnostic methodology of Madakku Pilavai. Chennai: National Institute of Siddha; 2017.

15. Srinivasan S. A study on Gunma Soolai. Chennai: National Institute of Siddha; 2007.

16. Dayanand RG, Sathiyarajeswaran $P$, Patturayan R, Ganesan R, Narasimha KGV, Dhanaraj K, Rama Devi B . Evaluation of acute, sub acute toxicity and immunomodulatory activity of Urai Mathirai-Siddha herbal formulation. J Glob Trends Pharm Sci. 2019;10(3):6372-82.

17. Santhammal Y, Arthika S, Sharly Elgal N, Ganesan R, Sathiyarajeswaran P, Gaidhani SN, Pramod Reddy G, Anadan T. Evaluation of immunomodulatory activity OF SAYA CHURNAM (a poly herbal formulation) on albino rats. J Adv Pharm Health Res. 2011;1(3):8-15.

18. Kavinilavan R, Mekala P, Raja Mj, Arthanari Eswaran M, Thirumalisamy G. Exploration OF immunomodulatory effect of Nilavembu Kudineer Chooranam against newcastle disease virus in backyard chicken. J Phar. Phy.2017;6(6):749-51.
19. Vaidya AD. An advocacy for Vaidya-scientists in ayurvedic research. J Ayurveda Integr Med. 2010;1(1):6-8. doi: 10.4103/0975-9476.59818, PMID 21829292.

20. Yang Y, Zhang Z, Li S, Ye X, Li X, He K. Synergy effects of herb extracts: pharmacokineticsand pharmacodynamicbasis. FITOTERAPIA. 2014;92:133-47. doi: 10.1016/j.fitote.2013.10.010, PMID 24177191

21. Prasad A, Muthamilarasan M, Prasad M. Synergistic antiviral effects against SARS-COV-2 by plant-based molecules. Plant Cell Rep. 2020;39(9):1109-14. doi: 10.1007/s00299-020-02560-w, PMID 32561979.

22. Mukherjee PK, Banerjee S, Kar A. Molecular combination networks in medicinal plants: understanding synergy by network pharmacology in Indian traditional medicine. Phytochem Rev. 2021. doi: 10.1007/s11101-020-09730-4.

23. Kiran G, Karthik L, Shree Devi MS, Sathiyarajeswaran P, Kanakavalli K, Kumar KM, Ramesh Kumar D. In silico Computational Screening of Kabasura Kudineer - Official Siddha Formulation And JACOM against Sars-Cov-2 Spike Protein. J Ayurveda Integr Med. 2020. doi: 10.1016/j.jaim.2020.05.009, PMID 32527713.

24. Shi Y, Wang Y, Shao C, Huang J, Gan J, Huang X, Bucci E, Piacentini M, Ippolito G, Melino G. COVID-19 infection: the perspectives on immune responses. Cell Death Differ. 2020;27(5):1451-4. doi: 10.1038/s41418-0200530-3, PMID 32205856

25. Liu J, Cao R, Xu M, Wang X, Zhang H, Hu H, Li Y, Hu Z, Zhong W, Wang M. Hydroxychloroquine, a less toxic derivative of chloroquine, is effective in inhibiting SARS-COV-2 infection in vitro. Cell Discov. 2020;6(1):1-4. doi: 10.1038/s41421-020-0156-0.

26. Chen Z, Hu J, Zhang Z, Jiang S, Han S, Yan D, Zhuang R, Hu B, Zhang Z. Efficacy of hydroxychloroquine in patients with COVID-19: results of a randomized clinical trial; 2020.

27. Mucklow JC. Thrombolytic treatment. Streptokinase is more economical than alteplase. BMJ. 1995;311(7018):1506. doi: 10.1136/bmj.311.7018.1506, PMID 8520368.

28. Rouf SA, Moo-Young M, Chisti Y. Tissue-type plasminogen activator: characteristics, applications and production technology. Biotechnol Adv. 1996;14(3):239-66. doi: 10.1016/0734-9750(96)00019-5, PMID 14537155.

29. Liu S, Feng X, Jin R, Li G. Tissue plasminogen activator-based nanothrombolysis for ischemic stroke. Expert Opin Drug Deliv. 2018;15(2):173-84. doi: 10.1080/17425247.2018.1384464, PMID 28944694.

30. Guidelines for Siddha practitioners for COVID 19 [press release]. NEW DELHI: MINISTRY OF AYUSH2020.

31. Ponkshe CA, Indap MM. In vivo and in vitro evaluation for immunomodulatory activity of three marine animal extracts with reference to phagocytosis. Indian J Exp Biol. 2002;40(12):1399-402. PMID 12974404.

32. Rawat P, Bachheti RK, Kumar N, Rai N. Phytochemical analysis and evaluation of in vitro immunomodulatory activity of Rhododendron arboreum leaves. Asian J Pharm Clin Res. 2018;11(8):123-8. doi: 10.22159/ajpcr.2018. v11i8.25372.

33. Ramesh KV, Padmavathi K. Assessment of immunomodulatory activity of Euphorbia hirta L. Indian J Pharm Sci. 2010;72(5):621-5. doi: 10.4103/0250474X.78532, PMID 21694995.

34. Mali RG, Bcjijops H. Nanotechnology. An in vitro study of effect of Centella asiatica on phagocytosis by human neutrophils. 2008;1(3):297-302.

35. Dagur PK, Mccoy JP. Collection, storage, and preparation of human blood cells. Curr Protoc Cytom. 2015;73(5 1):5.1.1-5.1.16 16. doi: 10.1002/0471142956. cy0501s73, PMID 26132177.

36. Khan IN, Habib MR, Rahman MM, Mannan A, Sarker MM, Hawlader S. Thrombolytic potential of ocimum sanctum L. Curcuma longa L., Azadirachta indica L. and Anacardium occidentale L. J Basic Clin Pharm. 2011;2(3):125-7. PMID 24826011.

37. Prasad S, Kashyap RS, Deopujari JY, Purohit HJ, Taori GM, Daginawala HF. Development of an in vitro model to study clot lysis activity of thrombolytic drugs. Thromb J. 2006;4:14. doi: 10.1186/1477-9560-4-14, PMID 16968529.

38. Upadhyay SN. Immunomodulation. Narosa Publishing House; 1997.

39. Qweider M, Gilsbach JM, Rohde V. Inadvertent intrathecal vincristine administration: a neurosurgical emergency. Case report. J Neurosurg Spine. 2007;6(3):280-3. doi: 10.3171/spi.2007.6.3.280, PMID 17355029.

40. Dhayalan M, Anitha Jegadeeshwari L, Nagendra Gandhi N. Biological activity sources from traditionally usedtribe and herbal plants material. Asian J Pharm Clin Res. 2015;8(6):11-23. 
41. Heroor S, Beknal AK, Mahurkar N. Immunomodulatory activity of methanolic extracts OF fruits and bark of Ficus glomerata ROXB. In mice and on human neutrophils. Indian J Pharmacol. 2013;45(2):130-5. doi: 10.4103/02537613.108287, PMID 23716887.

42. Mukherjee D, Khatua TN, Venkatesh P, Saha BP, Mukherjee PK. Immunomodulatory potential of rhizome and seed extracts of Nelumbo nucifera GAERTN. J Ethnopharmacol. 2010;128(2):490-4. doi: 10.1016/j. jep.2010.01.015, PMID 20079418.

43. Manosroi A, Saraphanchotiwitthaya A, Manosroi J. Effects of Pouteria cambodiana extracts on in vitro immunomodulatory activity of mouse immune system. FITOTERAPIA. 2006;77(3):189-93. doi: 10.1016/j. fitote.2006.01.003, PMID 16546328.

44. Panigada M, Bottino N, Tagliabue P, Grasselli G, Novembrino C, Chantarangkul V, Pesenti A, Peyvandi F, Tripodi A. Hypercoagulability OF COVID-19 patients in Intensive Care Unit: a report of thromboelastography findings and other parameters of hemostasis. J Thromb Haemost. 2020;18(7):1738-42. doi: 10.1111/jth.14850, PMID 32302438.

45. Connors JM, Levy JH. COVID-19 and its implications for thrombosis and anticoagulation. Blood. 2020;135(23):2033-40. doi: 10.1182/ blood.2020006000, PMID 32339221.

46. Ackermann M, Verleden SE, Kuehnel M, Haverich A, Welte T, Laenger F, Vanstapel A, Werlein C, Stark H, Tzankov A, Li WW, Li VW, Mentzer SJ, Jonigk D. Pulmonary vascular endothelialitis, thrombosis, and angiogenesis in COVID-19. N Engl J Med. 2020;383(2):120-8. doi: 10.1056/ NEJMoa2015432, PMID 32437596.

47. Klok FA, Kruip Mjha, Van Der Meer NJM, Arbous MS, GOmmers Dampj, Kant KM, Kaptein FHJ, van Paassen J, Stals MAM, Huisman MV, Endeman H. Incidence of thrombotic complications in critically ill ICU patients with COVID-19. Thromb Res. 2020;191:145-7. doi: 10.1016/j. thromres.2020.04.013, PMID 32291094

48. Aruna R, Sathiyarajeswaran P, Gopakumar K, Ramaswamy RS. J Phar Phytochemistry. Cardioprotective effects of kitchen culinaries mentioned in Siddha literature. 2014;3(3):71-9.

49. Sharma L. Hepatoprotective effect of Indian herbs and spices in alcoholinduced liver diseases. Vol. 12(02); 2018.

50. Li J, Liang Q, Sun GJCDM. Interaction between traditional Chinese medicine and anticoagulant/antiplatelet drugs. Curr Drug Metab. 2019;20(9):701-13. doi: 10.2174/1389200220666190827160212, PMID 31453781.

51. Akbar S. Zingiber officinale ROSC.(Zingiberaceae). Handbook of 200 medicinal plants. SPRINGER; 2020. p. 1957-97.

52. Meghwal M, Goswami TK. Piper nigrum and piperine: an update. Phytother Res. 2013;27(8):1121-30. doi: 10.1002/ptr.4972, PMID 23625885.
53. Rather RA, Bhagat M. Cancer chemoprevention and piperine: molecular mechanisms and therapeutic opportunities. Front Cell Dev Biol. 2018;6:10. doi: 10.3389/fcell.2018.00010, PMID 29497610.

54. Zheng J, Zhou Y, LI Y, XU DP, LI S, LI HB. Spices for prevention and treatment of cancers. Nutrients. 2016;8(8). doi: 10.3390/nu8080495, PMID 27529277.

55. Fox CB, Baldwin SL, Duthie MS, Reed SG, Vedvick TS. Immunomodulatory and physical effects of oil composition in vaccine adjuvant emulsions. Vaccine. 2011;29(51):9563-72. doi: 10.1016/j.vaccine.2011.08.089, PMID 21906648.

56. Fox CB, Baldwin SL, Duthie MS, Reed SG, Vedvick TS. Immunomodulatory and physical effects of phospholipid composition in vaccine adjuvant emulsions. AAPS PharmSciTech. 2012;13(2):498-506. doi: 10.1208/s12249012-9771-x, PMID 22415641.

57. Shanmuganathan S, Angayarkanni N. Chebulagic acid chebulinic acid and gallic acid, the active principles of TRIPHALA, inhibit tnfalpha induced pro-angiogenic and pro-inflammatory activities in retinal capillary endothelial cells by inhibiting P38, erk and NFkB phosphorylation. Vascul Pharmacol. 2018;108:23-35. doi: 10.1016/j.vph.2018.04.005, PMID 29678603.

58. Ezz-Eldin YM, Aboseif AA, Khalaf MM. Potential anti-inflammatory and immunomodulatory effects OF carvacrol against ovalbumin-induced asthma in rats. Life Sci. 2020;242:117222. doi: 10.1016/j.lfs.2019.117222.

59. Kianmehr M, Rezaei A, Boskabady MH. Effect of carvacrol on various cytokines genes expression in splenocytes of asthmatic mice. Iran J Basic Med Sci. 2016;19(4):402-10. PMID 27279984

60. Maatouk M, Mustapha N, Mokdad-Bzeouich I, Chaaban H, Abed B, laonnou I, Ghedira K, Ghoul M, Ghedira LC. Thermal treatment of luteolin-7-O-betaglucoside improves its immunomodulatory and antioxidant potencies. Cell Stress Chaperones. 2017;22(6):775-85. doi: 10.1007/s12192-017-0808-7, PMID 28578499.

61. Wangchuk P, Apte SH, Smout MJ, Groves PL, Loukas A, Doolan DL. Defined small molecules produced by Himalayan medicinal plants display immunomodulatory properties. Int J Mol Sci. 2018;19(11). doi: 10.3390/ ijms19113490, PMID 30404196.

62. Bala M, Pratap K, Verma PK, Singh B, Padwad Y. Validation of ethnomedicinal potential of Tinospora cordifolia for anticancer and immunomodulatory activities and quantification OF bioactive molecules by HPTLC. J Ethnopharmacol. 2015;175:131-7. doi: 10.1016/j.jep.2015.08.001, PMID 26253577.

63. Sharma U, Bala M, Kumar N, Singh B, Munshi RK, Bhalerao S. Immunomodulatory active compounds from Tinospora cordifolia. J Ethnopharmacol. 2012;141(3):918-26. doi: 10.1016/j.jep.2012.03.027, PMID 22472109.

64. Xu T, Kuang T, Du H, Li Q, Feng T, Zhang Y, Fan G. Magnoflorine: a review of its pharmacology, pharmacokinetics and toxicity. Pharmacol Res. 2020;152:104632. doi: 10.1016/j.phrs.2020.104632.

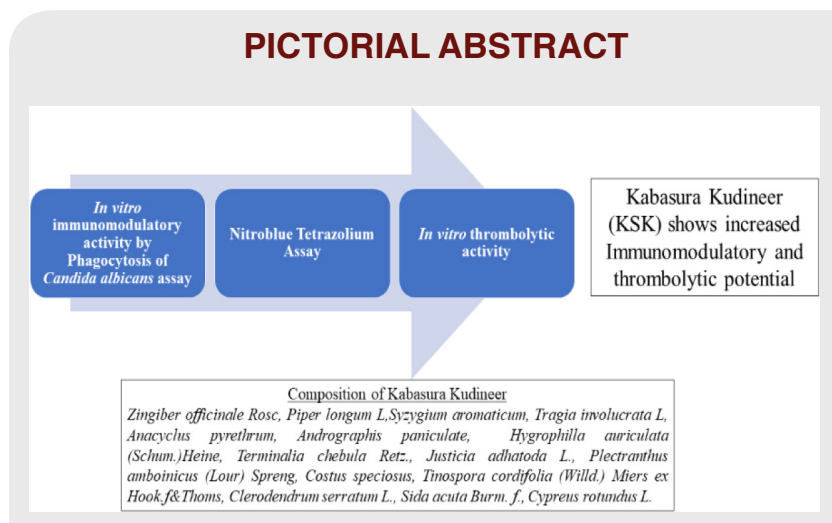

\section{SUMMARY}

The present experimental paper details the utilisation and application of the KSK extract as an immunomodulatory substance for the improvement in human immune response

\section{About Authors}

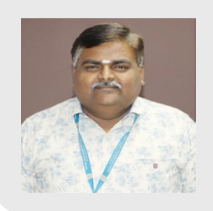

Parameswaran Sathiyarajeswaran is working as Asst. Director \& In-Charge (Scientist 3), Siddha Central Research Institute, CCRS, Chennai. He has completed M.D in Siddha and has more than 10 years of experience in Clinical Research in Siddha. He has more than 70 publications in peer reviewed journals. 

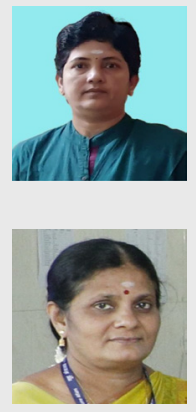

Shree Devi Munusamy Sampangi Ramulu is working as Research Officer and HOD Pharmacy at Siddha Central Research Institute, CCRS, Chennai. She has an experience of 10 years and published more than 90 publications in peer reviewed journals.

Kadarkarai Kanakavalli is the Director General of Central Council for Research in Siddha, Chennai.

Loganathan Karthik working as a Project Lead-Synthetic biology, Salem Microbes Pvt.Ltd, Salem, Tamil Nadu, India. He is an elected member of Linnean Society of London. He has published more than 70 papers and 4 books.

Arivarasan Vishnukirthi has an extensive expertise in Nanotechnology and Drug Delivery Strategies and is presently working as a Post-doctoral research scientist at the National Centre for Nanotechnology and Nanosciences, University of Mumbai, Mumbai. He has published more than 64 papers and 3 books.

Dhanakoti Ramesh Kumar is a Managing Director of Salem Microbes Private Limited, Salem, Tamil Nadu, India.

Cite this article: Parameswaran S, Sampangi Ramulu SDM, Arivarasan VK, Kadarkarai K, Dhanakoti RK, Loganathan K. Evaluation of in-vitro Immunomodulatory Activity and Thrombolytic Potential of Kabasura Kudineer (KSK): An Official Siddha Polyherbal Formulation. Indian J of Pharmaceutical Education and Research. 2021;55(3):774-81. 